\title{
HYALE TRIDENTATA.
}

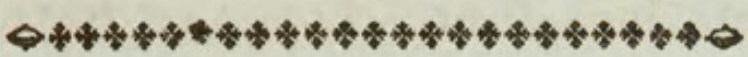

\section{CHARACTER GENERICUS.}

\section{Animal Clio.}

Testa bivalvis, tenuis; valvulis connatis: superiore inflato-convexa, inferiore planiuscula.

\section{CHARACTER SPECIFICUS, \&c.}

HYALE testa pallida, fusco-flavente, extremitate inferiore tridentata.

ANOMIA tridentata. A.

\section{HYALE.}

Cuvier. Ann. Mus. Hist. Nat. No. 21. p. 223. N. B. Figuræ superiores et inferiores leviter auctæ; cæteræ magnitudine vera exprimuntur.

A testa pellucida nomen adeptum est genus Hyale; accurate descriptum et depictum a Domino Cuviero in opere cui titulus " Annales," \&c. Testam primus detexit Dominus Forskalius, et ad genus Anomice retulit, cujus habita est species ano. mala. In mari Mediterraneo enutritum summas 
radit aquas quo modo solet genus Clio, e Molluscorum familia; cui affine admodum est, animal quod in testa includitur. Longa est testa, ut plurimum, quasi tertiam unciæ partem, interdum pertingens ultra unciam dimidiatam. Color levissime fusco-flavescit. 

$66_{4}$
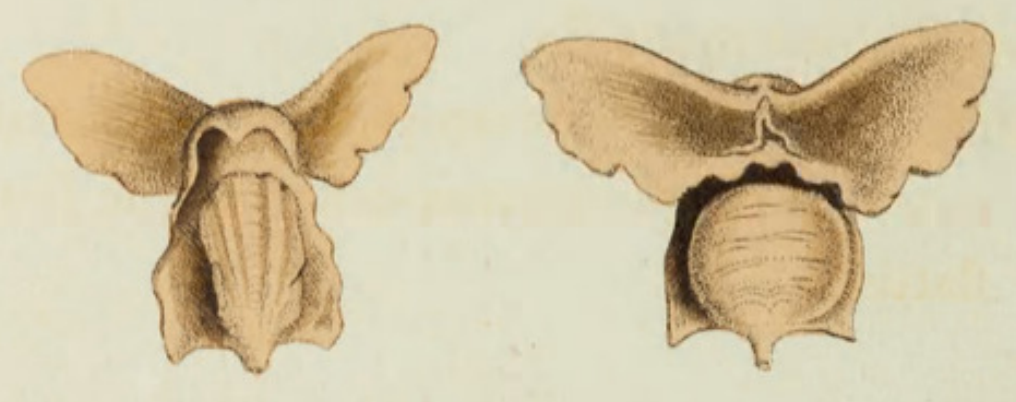

Q

20
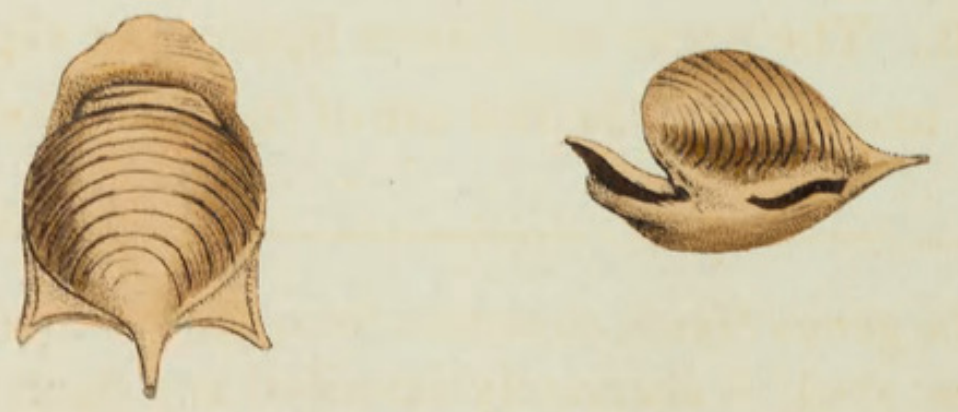

RTS Srutent 


\section{THE \\ TRIDENTATED HYALE.}

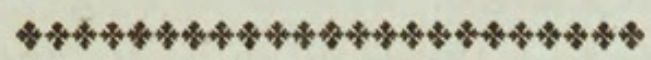

GENERIC CHARACTER.

Animal allied to a Clio.

Shell bivalve, thin, subtransparent; valves connate ; the upper convex-inflated, the lower flattish.

SPECIFIC CHARACTER, E्C.

Pale yellowish-brown Hyale, with the shell tridentated at the lower part.

HYALE.

Cuvier. Ann. Hist. Nat. No. 21.p. 194. N. B. The upper and lower figures are slightly magnified; the rest are of the natural size.

The genus Hyale, so named from the transparency of the shell, is accurately described and figured by Mons. Cuvier in the "Annales du M. N. d'Hist. Nat." By Forskal, its first describer, it was referred to the genus Anomia, of which it was al- 
lowed to constitute an anomalous species. It is a native of the Mediterranean sea, and is observed to swim on the surface in the manner of the genus Clio among the Mollusca, to which its inhabiting animal is much allied. The usual length of the shell is from one to two-thirds of an inch, and its colour a very pale yellowish brown. 


\section{$2 \mathrm{BHL}$ Biodiversity Heritage Library}

Shaw, George. 1805. "The Tridentated Hyale, Hyale tridentata [PI. 664]." The Naturalist's Miscellany 16(CLXXXVIII), https://doi.org/10.5962/p.311104.

View This Item Online: https://www.biodiversitylibrary.org/item/281942

DOI: https://doi.org/10.5962/p.311104

Permalink: https://www.biodiversitylibrary.org/partpdf/311104

\section{Holding Institution}

Museums Victoria

\section{Sponsored by}

Atlas of Living Australia

\section{Copyright \& Reuse}

Copyright Status: Public domain. The BHL considers that this work is no longer under copyright protection.

This document was created from content at the Biodiversity Heritage Library, the world's largest open access digital library for biodiversity literature and archives. Visit BHL at https://www.biodiversitylibrary.org. 